\title{
The Development of Supplements Book in Geography Subject Studies for Senior High School Student
}

\author{
Syafrida Selfiardy $^{1}$, Sarwono $^{2}$, Puguh Karyanto ${ }^{1}$ \\ ${ }^{1}$ Master Studies of Education and Environmental Education, Faculty of Teacher Training and Education, \\ Sebelas Maret University, \\ Email: sssyafrida@gmail.com
}

\begin{abstract}
Based on the need assassement (including instructional analysis and analyze learners and context), the supplement book of geography is necessary to be developed. This research was conducted in order to develop a supplement book for hydrosphere material that can be used as an educative learning tool for students outside geography lesson at school. Starting from the needs analysis (including learning analysis and learner and context analysis) conducted by researcher in class XI Social 3 Senior High School of Muhammadiyah 1 Ponorogo, researchers get the data as follows. The result of requirement analysis on the result of lecturer and context analysis is known the highest percentage of $34,4 \%$ students of class XI Social 3 use textbook, notes from teacher, and others as learning source to learn geography. Another learning resource that students use when studying geography is internet that is as much as $87 \%$. This is a compelling reason why supplement book products need to be developed. The development model in this research using Dick and Carey development model. The steps of Dick and Carey model are: (1) need assessement; (2) conduct instructional analysis; (3) analyze learners and context; (4) write performance objectives; (5) develop assessement instruments; (6) develop instructional strategy; (7) develop and select instructional materials; (8) design and conduct formative evaluation of instruction; (9) revise instruction; (10) summative evaluation. In this development research, researchers only go through the ninth stage, i.e. until the stage of revision. This is because of the limited time and cost if doing until the tenth stage.
\end{abstract}

Keywords: learning resources, supplements, hydrosphere

\section{INTRODUCTION}

Implementation of learning activities in formal education in schools can not be separated from the role of the curriculum as a guide for learning activities. Curriculum is the study of any and all educational phenomena [1]. According to the concept of curriculum as a plan, curriculum is a sort of blueprint for systematically implementing educational activities [2]. In accordance with the understanding of the curriculum above, that teachers use the curriculum as a classroom teaching guide. Teacher teaching activities in the classroom will be more structured and have a special purpose with the curriculum. The specific purpose of the curriculum is the standard of graduation education that students must achieve at a certain level of education. 
Beginning of academic year 2016/2017 education system in Indonesia experiencing curriculum change that is 2013 curriculum revision year 2016. In Regulation of Minister of Education and Culture Number 20 Year 2016 about Standard of Competence of Graduate of Elementary and Secondary Education explained that competency standard of graduates in high school cognitive level have Factual, conceptual, procedural, and metacognitive knowledge. Factual includes technical and specific, detailed and complex knowledge related to science, technology, art and culture related to society and surrounding natural environment, nation, country, regional, and international. Conceptual means terminology / terminology and classification, categories, principles, generalizations, theories, models, and structures used in connection with technical and specific knowledge, detailed and complex with respect to science, technology, art and culture related to society and the surrounding natural environment , Nation, state, regional, and international. Procedural is the knowledge of how to do something or activity related to technical knowledge, specific, algorithm, method, and criteria to determine the appropriate procedure related to science, technology, art, and culture, related to society and surrounding natural environment, nation, Countries, regional regions, and internationally. Metacognitive is knowledge of the strengths and weaknesses of oneself and uses them in the study of technical, detailed, specific, complex, contextual and conditional knowledge related to science, technology, art and culture related to society and the natural environment, nation, state, regional, and international.

To achieve the defined competency standards of graduates, it is necessary to establish the content standards, which are the criteria of the scope of the subject matter and the level of competence of learners. The competency standards of graduates for high school cognitive domain are factual, conceptual, procedural, and metacognitive as described previously. Then the standard of content to be able to achieve the four competency standards of graduates in the cognitive domain is contained in the Regulation of the Minister of Education and Culture No. 21 of 2016 on Basic Content of Basic and Intermediate Education, which is understanding, applying, analyzing and evaluating factual, conceptual, procedural, and metacognitive knowledge The technical, specific, detailed, and complex levels based on his curiosity about science, technology, arts, culture and humanities with the insights of humanity, nationality, state and civilization on the causes of phenomena and events, and applying knowledge to specific areas of study with his talents and interests to solve problems.

Student learning activities are pure personal involving the student to learn the knowledge from her own experience. Personal experience (observation) activities are part of classroom learning activities with duration of three hours of lessons per week. The three hours of lessons per week included questioning, association, concluding, and communicating. The personal experience activities carried out in classroom learning have only a relatively short time, whereas the purpose of the activity is to improve the effectiveness of the understanding.

Geography is the science of spatial relations and places on the surface of the earth [3]. Geography subjects studied in high school have been studied as a unity of geography. Geography has a multi-varied field of study in which different areas of study are studied and form a solid science unit [4]. Three hours of study in a week, with extensive geography course studies and an assessment that includes affective, cognitive, and psychomotor aspects proportionally, making geography insufficient to learn only in school hours. There is a need for learning resources other than teachers and textbooks 
that can support the learning of geography and can support in learning geography outside school.

One of the ways in which students can learn geography outside school hours is by reading from various sources of reading. Many things students can get from reading. Reading geography reading outside school hours helps students better understand the material they have learned in school. Be sides, the benefit of pre-reading assignment before the class will learn the basic definitions and vocabulary, as well as having the concepts at their own Pace. This helps control for what is covered in class [5]. Without books (and textbooks are included here), no education could have been possible. They are the primary source of information used by all humanity. After the invention of the typewriter, the printing of the textbooks and books in general accomplished high peaks and expanded its readership [6].

Picture story book is one way that can be attempted so that the hydrosphere material can be increasingly understood by the students. Anything not found in textbooks can be obtained by reading picture books on hydrosphere material. Such additional material may concern the theory, the true story of the local wisdom of a population, and so forth, which will later be explained through the collaboration of stories and images. Picture as one of the communication media complete writing in explaining the existence of an object. Images are an effective medium for expressing ideas because they are easier to digest. The continuity between drawing and an interesting storyline can stimulate the brain to receive messages and remember them well.

Picture story book is one effort that can be done so that material hydrosphere more understandable by student. In addition, picture book books can be read outside of school hours, so abbreviate activities in the classroom to be used for other activities such as asking teachers, discussions, and presentations.

\section{METHOD}

This study uses a descriptive procedural development model, which outlines the steps that must be followed to produce the product. The development model in this research uses Dick and Carey development model. The Dick and Carey development model has ten stages: (1) needs analysis, (2) learning analysis, (3) learner and context analysis, (4) formulating performance goals, (5) developing instruments, (6) developing learning strategies , (7) developing and selecting learning materials, (8) designing and conducting formative evaluation, (9) revising, (10) summative evaluation[7]. In this development research, researchers only go through the ninth stage, i.e. until the stage of revision. This is because of the limited time and cost if doing until the tenth stage. The research steps as follows:

At the data collection stage, the researcher using a questionnaire to collect needs assessement data, validation sheet for assessment by validator, and questionnaire to collect student response data on supplement book. To analyze the data, the researcher using percentage analysis to analyze data from the validators, and using mode (basic of statistics) analysis to analyze the effectiveness of the product. 


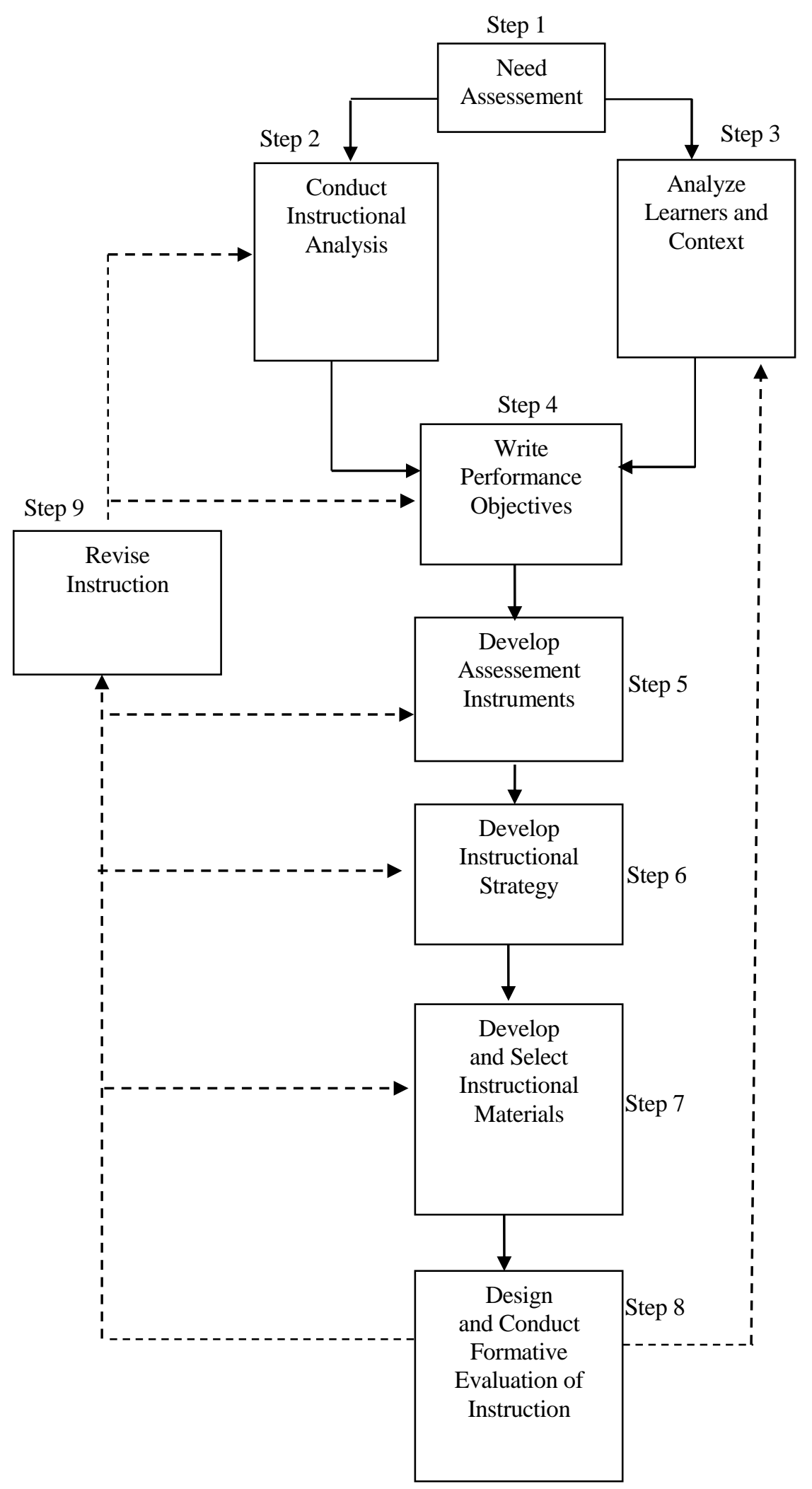

Figure 1. The Systematic Design of Instruction by Dick\&Carey with Alteration [7] 


\section{RESULT}

\section{Need Assessement}

Needs analysis data is obtained from questionnaire needs analysis and also includes learner and context analysis. The results of the needs analysis are divided into the learning analysis phase to the curriculum and the learner and context analysis to the students. The results of analysis on needs analysis are explained in detail in the learning and learning analysis of the learner and the context below.

\section{Conduct Instructional Analysis}

Developers use the Regulation of the Minister of Education and Culture No. 20 of 2016 [8] on Competency Standards Graduates of Primary and Secondary Education as a reference to analyze the learning needs, where the results of learning analysis used to design products that have been developed. The passing standard specified in the 2013 Curriculum of the 2016 revision needs to be realized by meeting the content standards set forth in the Regulation of the Minister of Education and Culture No. 21 of 2016 [9] on Content Standards.

Content standards covering the substance of the scope of the material and the competency level of the students are tailored to the core competencies and basic competencies contained in the Regulation of the Minister of Education and Culture No. 24 of 2016 [10]. Substantial substances in the content standards that have been adapted to core competencies and competencies are essentially applied according to process standards and Evaluated / assessed in accordance with assessment standards.

Principles of learning in accordance with product specifications made by developers as stipulated in the Regulation of the Minister of Education and Culture No. 22 of 2016 [11] on Standard Process include: from learners are told to learners to find out; from the teacher as the only source of learning to learn based on various learning resources.

From the above principles of learning, students are expected to be able to apply the learning process as designed by the government, but the fact that there is a gap between the situation should be with the real situation in the field (described in the learner's analysis and context). The difference is used by developers as a supporting reason in order to develop a product of illustrated books of science stories of hydrosphere material on high school geography subjects

\section{Analyze Learners and Context}

Through a questionnaire of needs analysis, the developer analyzes the learner and the context, which includes learning resources that students use in geography, students' assessment of the learning resources they are using, and the readiness of students to receive research products. Here are the results of learner and context analysis on the material related to the development of hydrosphere product of science picture book series that was done in class XI IPS 3 Senior High School of Muhammadiyah 1 Ponorogo, East Java, Indonesia. 


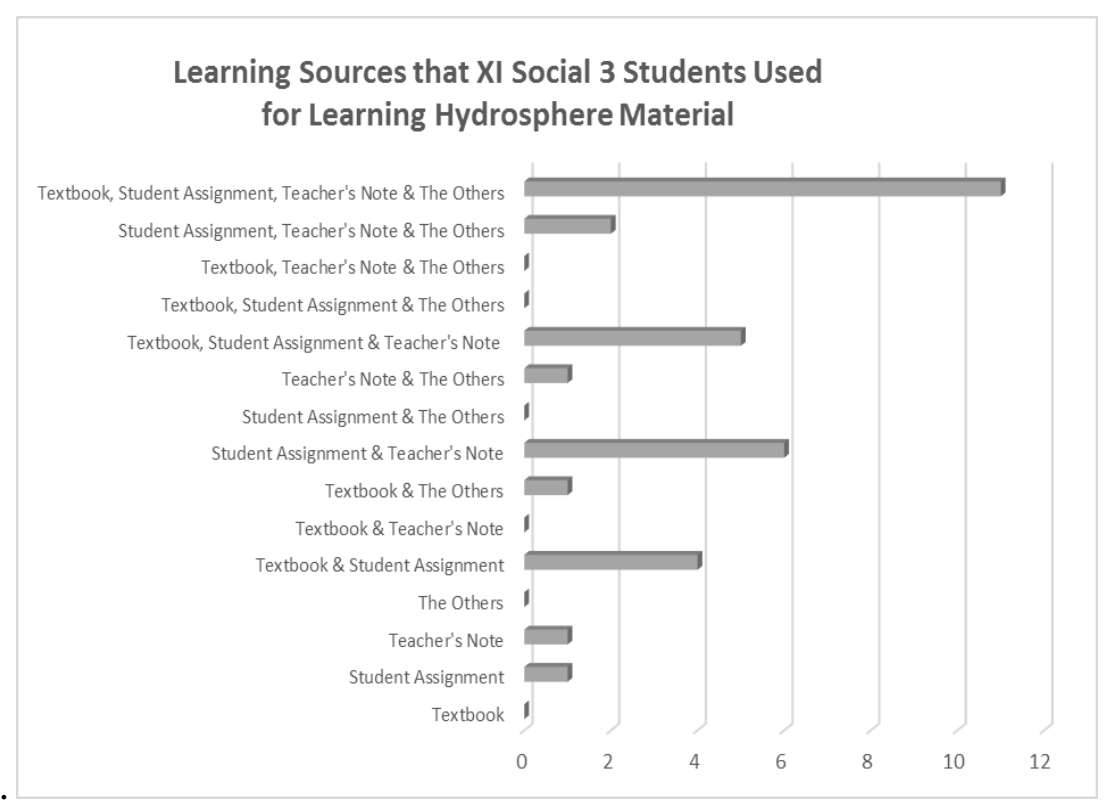

Figure 2. For Learning Hydrosphere Material

Other options are deliberately emptied by the developer on the questionnaire. It is intended that students fill in their own learning resources that they normally use when learning geography without being tied to the options / options provided by the developer. On this occasion the developer would like to see the variety of learning resources that students use to help them understand geography lessons. Results of other options that students have filled in the questionnaire needs analysis are as follows.

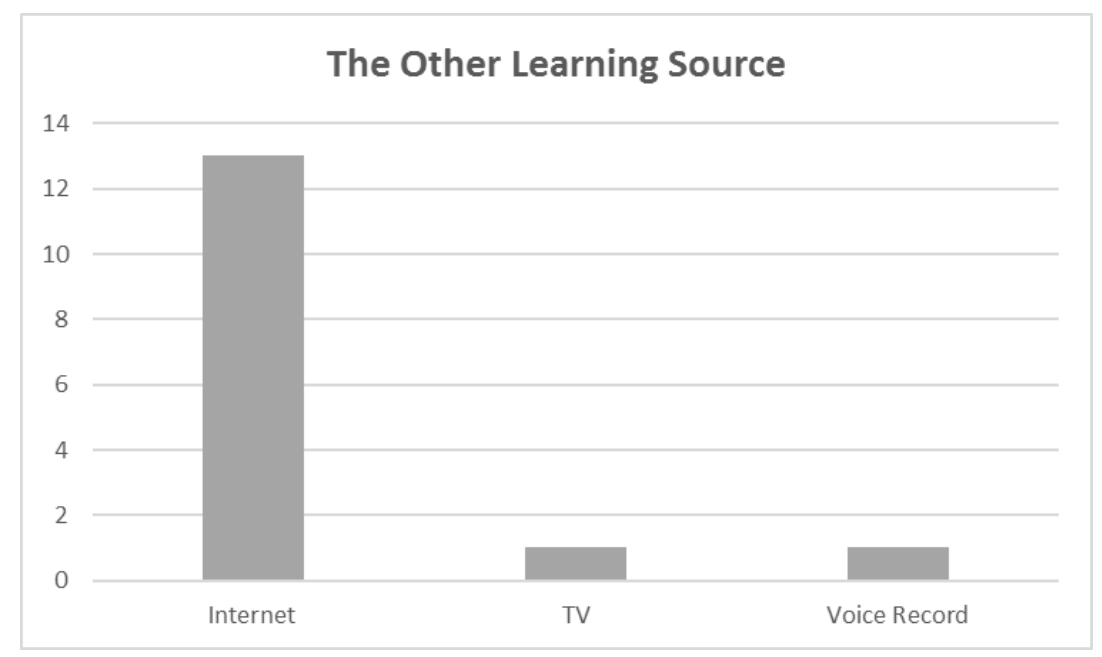

Figure 3. The Other Learning Source

\section{Write Performance Objectives}

Performance goals are made to formulate specific objectives of product research development. Steps to formulate performance objectives are done by reviewing the results of the assessment of needs analysis and general purpose of developing a product of a scientific picture story into a special purpose. Specific objectives that have been formulated from the analysis of needs and general goals provide information to develop 
test items. As a specific objective developed from the analysis of general needs and objectives, the objectives of performance are indicators that match the competencies that have been studied in the learning analysis. These indicators are used as specific goals of the achievement of the development of scientific picture book products.

Indicators of achievement of specific objectives of this development study can be seen in the table below.

TABLE 1 INDICATORS OF ACHIEVEMENT OF LEARNING OUTCOMES AS A SPECIAL PURPOSE OF DEVELOPMENT RESEARCH

\begin{tabular}{|c|c|c|}
\hline Subject & Basic Competency & Indicators \\
\hline Hydrosphere & 3.7 Analyze the & 1) Identify the main elements of the hydrological \\
\hline Dynamics and Its & dynamics of the & cycle. \\
\hline \multirow[t]{2}{*}{ Impact on Life } & $\begin{array}{l}\text { hydrosphere and its } \\
\text { impact on life }\end{array}$ & $\begin{array}{l}\text { 2) Identify and analyze the various types of marine } \\
\text { water and their problems. }\end{array}$ \\
\hline & & $\begin{array}{l}\text { 3) Apply procedural knowledge to safeguard and } \\
\text { overcome the problems of adjacent coastal and } \\
\text { marine waters. }\end{array}$ \\
\hline
\end{tabular}

From the indicator table achievement of learning achievement as a special purpose of development research above, then used as a reference to make test items to measure whether the indicators can be achieved students after reading the product of a scientific story book or not.

\section{Develop Assessement Instruments}

This development research uses two types of instruments, namely document analysis instruments and questionnaires. Document analysis instruments are used by linguists to rate / validate supplement book products. The questionnaire instrument is used by material experts, media experts, geography teachers, and test subjects to rate supplement book products.

The development tools in a language validator use a questionnaire in the form of a recommendation sheet that uses open-ended questions. Questionnaire with an open question expects the linguist's validator to write his answer on a recommendation sheet on his judgment on the supplement book. On validation questionnaires by media experts, materials, geography teachers, and trial subjects are used questionnaires that use closed questions.

\section{Develop Instructional Strategy}

The stage of developing learning strategies helps developer to achieve specific goals. There are several steps that developer do in developing a scientific picture book, as shown in the chart below. 


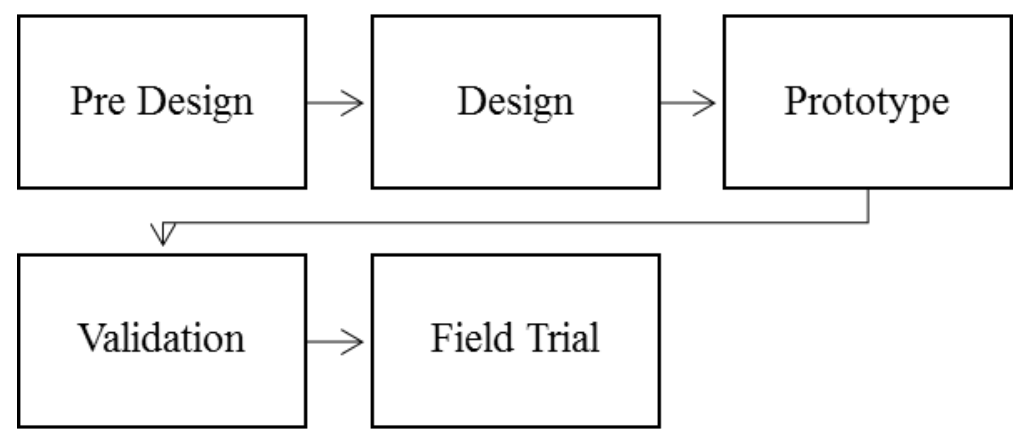

Figure 4. Develop Instuctional Strategy

The pre-design stage is the stage where the developer analyzes the teaching materials to achieve the specific objectives in accordance with the competency standards of the graduates. The second stage is the design. In the process of the design phase, there are five steps taken, namely: (1) collecting data (reference books and pictures / photos); (2) create a storyboard; (3) compiling material and stories; (4) integrating materials and stories with pictures / photographs; And (5) the process of layout of a scientific picture book. The third stage is a prototype of a scientific picture book. The prototype of a scientific picture book is a finished product in the layout and ready to be validated by validators and practitioners. The book prototype can not be tested before going through the validation process. The fourth stage is validation. There are three validators and one practitioner who evaluate this product. This assessment aims to make the product truly ready for use by students. The fifth stage is a trial. Field trials are conducted after revising the product using a revision of the validator.

\section{Develop and Select Instructional Materials}

The material used in product development is a hydrosphere, contained in the class $\mathrm{X}$ geothermal subjects. The developed hydrosphere science story book has been adapted to the Core Competencies and Basic Competencies based on the 2016 revision of the 2016 curriculum. Materials developed in the Hydrosphere chapter are as follows: (1) the water cycle; (2) marine waters; and (3) surface water (covering rivers, lakes, and ground water).

Differences in the material presentations in the supplement book with textbooks lie in the use of language, presentation of case studies, and are complemented by imagery to make it easier for readers to see landscapes with actual images (not illustrative drawings).

\section{Design and Conduct Formative Evaluation of Instruction}

Formative evaluation is intended to test the effectiveness of the product. There are two stages in formative evaluation activities. First is a product prototype test by a validator (validator of linguists, media, materials and practitioners) and second is a product effectiveness test by students who have studied hydrosphere material. 
The instrument used by the linguist's validator to assess this product is a document analysis instrument in the form of a recommendation sheet. The input and suggestion results by expert language validators can be seen in the following table.

TABLE 2. SUGGESTION FOR IMPROVEMENT RESULT

\begin{tabular}{|c|c|c|c|}
\hline No. & $\begin{array}{c}\text { Validated } \\
\text { Components }\end{array}$ & Assessment & Suggestion for Improvement \\
\hline \multicolumn{4}{|c|}{ Linguistic Components } \\
\hline 1. & Legibility & $\begin{array}{l}\text { The vocabulary used is the } \\
\text { vocabulary / term for the field } \\
\text { of geography, and has been } \\
\text { given explanation by the } \\
\text { author. }\end{array}$ & $\begin{array}{l}\text { - Vocabulary in a particular field of } \\
\text { knowledge is recommended to be } \\
\text { tilted. }\end{array}$ \\
\hline 2. & $\begin{array}{l}\text { Clarity of } \\
\text { Information }\end{array}$ & $\begin{array}{l}\text { - Related information in the } \\
\text { form of images, the author } \\
\text { should pay attention to the } \\
\text { effectiveness of the picture. }\end{array}$ & $\begin{array}{l}\text { - Images that do not support better } \\
\text { material are not listed. In contrast, } \\
\text { images that support the material } \\
\text { should be described in the image. }\end{array}$ \\
\hline \multicolumn{4}{|c|}{ General Spellings Guidelines for Indonesian } \\
\hline 3. & Writing Words & $\begin{array}{l}\text { - Authors should pay attention } \\
\text { to beheading. }\end{array}$ & $\begin{array}{l}\text { - The beheading must pay attention } \\
\text { to its basic form of speech, so as } \\
\text { not to change the meaning } \\
\text { conveyed. }\end{array}$ \\
\hline 4. & $\begin{array}{l}\text { Use of } \\
\text { Punctuation and } \\
\text { Elements }\end{array}$ & $\begin{array}{l}\text { - The use of punctuation and } \\
\text { absorption is quite good. } \\
\text { Some errors please be } \\
\text { revised }\end{array}$ & $\begin{array}{l}\text { - Errors that have been given } \\
\text { examples of justification by the } \\
\text { linguist on the product related to } \\
\text { the use of punctuation and the } \\
\text { element of absorption are advised } \\
\text { to be revised. }\end{array}$ \\
\hline
\end{tabular}

The results of validation by using a questionnaire assessment / validation of media experts on the book supplement story scientific images are as follows.

TABLE 3. RESULTS OF VALIDATION BY USING A QUESTIONNAIRE ASSESSMENT

\begin{tabular}{|c|c|c|c|c|c|}
\hline No. & Validated Components & Score & $\begin{array}{l}\text { Maximum } \\
\text { Score }\end{array}$ & $\%$ & Conclusion \\
\hline \multicolumn{6}{|c|}{ Feasibility of Presentation } \\
\hline 1. & $\begin{array}{l}\text { Table of Contents } \\
\text { Load chapter titles, sub chapters of } \\
\text { text section with page numbers. }\end{array}$ & 4 & 5 & 80 & Good/revision \\
\hline 2. & $\begin{array}{l}\text { Bibliography } \\
\text { The list of books / journals used as } \\
\text { reference material is written in the } \\
\text { correct authorship format. }\end{array}$ & 4 & 5 & 80 & Good/revision \\
\hline \multicolumn{6}{|c|}{ Channel Feasibility } \\
\hline 3. & $\begin{array}{l}\text { The supplement book cover is } \\
\text { visually clear, contrasting, }\end{array}$ & 4 & 5 & 80 & Good/revision \\
\hline 4. & $\begin{array}{l}\text { interesting, and depicting content. } \\
\text { The material in the supplement book } \\
\text { is presented in text form, and the } \\
\text { illustration of the image is displayed }\end{array}$ & 4 & 5 & 80 & Good/revision \\
\hline 5. & $\begin{array}{l}\text { in a communicative, harmonious, } \\
\text { and proportional manner. } \\
\text { The selection of illustrations is }\end{array}$ & 4 & 5 & 80 & Good/revision \\
\hline
\end{tabular}


TABLE 3, CONT.

\begin{tabular}{|c|c|c|c|c|}
\hline $\begin{array}{l}\text { tailored to the content / material on } \\
\text { the supplement book. } \\
\text { Supplementary book format is } \\
\text { determined based on the level of } \\
\text { legibility that can be achieved and } \\
\text { meet the aspects of effective and } \\
\text { efficient. }\end{array}$ & 4 & 5 & 80 & Good/revision \\
\hline Total & 24 & 30 & 80 & Good/revision \\
\hline
\end{tabular}

The validation result by using questionnaire's assessement of the material expert to the supplement book are as follows.

TABLE 4. VALIDATION RESULT BY USING QUESTIONNARIES ASSESSEMENT OF THE MATERIAL EXPERT

\begin{tabular}{|c|c|c|c|c|c|}
\hline No. & Validated Components & Score & $\begin{array}{l}\text { Maximum } \\
\text { Score }\end{array}$ & $\%$ & Conclusion \\
\hline \multicolumn{6}{|c|}{ I. Feasibility of Content } \\
\hline \multicolumn{6}{|c|}{ A. Material Coverage } \\
\hline & Material Extension & 5 & 5 & 100 & Very good \\
\hline 2. & Depth of Material & 4 & 5 & 80 & Good/revision \\
\hline 3. & $\begin{array}{l}\text { There is a purpose learning subject in the } \\
\text { material }\end{array}$ & 4 & 5 & 80 & Good/revision \\
\hline \multicolumn{6}{|c|}{ B. Material Accuracy } \\
\hline & $\begin{array}{l}\text { The truth of the theory or concept of } \\
\text { hydrosphere matter }\end{array}$ & 4 & 5 & 80 & Good/revision \\
\hline 5. & $\begin{array}{l}\text { Images / illustrations are presented in } \\
\text { accordance with the field } \\
\text { The conformity of the use of the term }\end{array}$ & 4 & 5 & 80 & Very Good \\
\hline \multicolumn{6}{|c|}{ C. Material Updates } \\
\hline & $\begin{array}{l}\text { Compatibility with the development of } \\
\text { geography }\end{array}$ & 3 & 5 & 60 & $\begin{array}{l}\text { Good enough / } \\
\text { revision }\end{array}$ \\
\hline 7. & $\begin{array}{l}\text { Recency / feature availability (examples) } \\
\text { and references } \\
\text { Example of case / story according to the } \\
\text { environment around student }\end{array}$ & 3 & 5 & 60 & $\begin{array}{l}\text { Good enough / } \\
\text { revision }\end{array}$ \\
\hline
\end{tabular}

\begin{tabular}{|c|c|c|c|c|c|}
\hline \multicolumn{6}{|c|}{ II. Feasibility of Presentation } \\
\hline \multicolumn{6}{|c|}{ A. Serving Systematics } \\
\hline 8. & $\begin{array}{l}\text { The systematic presentation of matter } \\
\text { obeys the principle of the demands of the } \\
\text { introduction, content, and closing }\end{array}$ & 4 & 5 & 80 & Good/revision \\
\hline 9. & $\begin{array}{l}\text { Present the coherent material from simple } \\
\text { matter to complex material } \\
\text { Develop academic skills }\end{array}$ & 4 & 5 & 80 & Good/revision \\
\hline \multicolumn{6}{|c|}{ B. Supporting the Presentation } \\
\hline 10. & $\begin{array}{l}\text { There are examples of cases as an exercise } \\
\text { of students' understanding of the material } \\
\text { There is a picture / photo as an exercise of }\end{array}$ & 5 & 5 & 100 & Very Good \\
\hline \multicolumn{2}{|r|}{$\begin{array}{l}\text { There is a bibliography with standard } \\
\text { Thents' understanding of the material }\end{array}$} & 5 & 5 & 100 & Very Good \\
\hline & Total & 45 & 55 & 81 & Good/revision \\
\hline
\end{tabular}


Validation results by using questionnaire assessment/validation by geography teacher to supplement book is as follows.

TABLE 5. VALIDATION RESULT BY USING QUESTIONNARIES ASSESSEMENT OF GEOGRAPHY TEACHER

\begin{tabular}{|c|c|c|c|c|c|}
\hline No. & Validated Components & Score & $\begin{array}{l}\text { Maximum } \\
\text { Score }\end{array}$ & $\%$ & Conclusion \\
\hline \multicolumn{6}{|c|}{ Feasibility of Content } \\
\hline 1. & $\begin{array}{l}\text { Core competence is explicity listed as the } \\
\text { title of the chapter, subtitles in the chapter. }\end{array}$ & 4 & 5 & 80 & Good/revision \\
\hline 2. & Basic competence is explicity listed as as & 4 & 5 & 80 & Good/revision \\
\hline 3. & $\begin{array}{l}\text { sub-chapter title. } \\
\text { The conformity of supplement book } \\
\text { contents with core competence and the forth } \\
\text { basic competence. }\end{array}$ & 5 & 5 & 100 & Very Good \\
\hline \multicolumn{6}{|c|}{ Feasibility of Presentation } \\
\hline 4. & $\begin{array}{l}\text { Table of Contents } \\
\text { Load chapter titles, sub chapter of text } \\
\text { section with page numbers. }\end{array}$ & 4 & 5 & 80 & Good/revision \\
\hline 5. & $\begin{array}{l}\text { Bibliography } \\
\text { The list of books/journals used as reference } \\
\text { material is written in the correct authorship } \\
\text { format. }\end{array}$ & 4 & 5 & 80 & Good/revision \\
\hline \multicolumn{6}{|c|}{ Channel Fisability } \\
\hline 6. & $\begin{array}{l}\text { The supplement book cover is visually clear, } \\
\text { contrasting, interesting, and depicting } \\
\text { content. }\end{array}$ & 4 & 5 & 80 & Good/revision \\
\hline 7. & $\begin{array}{l}\text { The material in the supplement book is } \\
\text { presented in text form, and the illustration of } \\
\text { the image is displayed in a communicative, } \\
\text { harmonius, and proortional manner.. }\end{array}$ & 4 & 5 & 80 & Good/revision \\
\hline & TOTAL & 29 & 35 & 83 & Good/Revision \\
\hline
\end{tabular}

After the product is declared eligible by linguist, media expert, material expert, and practitioner to be tested, the next step is to test the effectiveness of the product. Trial of product effectiveness is done in class XI Social 3 Senior High School of Muhammadiyah 1 Ponorogo. The test subjects were 32 students who had read the book product of a scientific illustrated story of hydrosphere. Based on data from questionnaire of student appraisal, obtained data as follows.

\section{TABLE 6. VALIDATION RESULT BY USING QUESTIONNARIES ASSESSEMENT OF} STUDENT APPRAISAL

\begin{tabular}{llc}
\hline No. & Mode Value & Conclusion \\
\hline Linguistic Component & & \\
\hline $1 . \quad$ The clarity of reading on a scientific picture book. & 3 & Obviously \\
\hline Channel Fisability & 3 & \\
\hline $2 . \quad \begin{array}{l}\text { Understanding students increases after observing the } \\
\text { pictures/photos on the supplement book. }\end{array}$ & & Agree \\
\hline Component of Content Fisability & 3 & \\
\hline $3 . \quad$ Ease students understand the material on the supplement & 4 & Easy \\
$4 . \quad$ book. & 3 & Definitely Agree \\
$5 . \quad$ There is a new knowledge that students get after reading a
\end{tabular}


TABLE 6, CONT.

supplement book.

Students are excited about studying the hydrosphere material using a supplement book.

\begin{tabular}{lll}
\hline Serving Component & & \\
\hline $6 . \quad$ The supplement book draws in its entirety (layout, & 4 & Very Interesting \\
language, material, and image).
\end{tabular}

\section{CONCLUSION}

Characteristics of the supplement book compared with learning resources used by students lies in terms of language, image / photo, book appearance, and material coverage. The supplement book has a more communicative style of language, accompanied by stories about case studies or events that are closely related to the lives of everyday students. Picture / photo on color supplement book, accompanied by image of landscape image from image. The display of the book (layout) is colorful. The scope of the material in the supplement book is more depth than the textbooks in the school.

Based on the results of validation / assessment from linguists, media, materials, practitioners, field trials, to pre-test and post-test, it is concluded that the supplement book of scientific illustrated story of hydrosphere is suitable for students as a learning resource to study geography subjects.Bottom of Form

\section{REFERENCES}

[1] Egan, K. (2003). What Is Curriculum? Journal of the Canadian Association for Curriculum Studies, Vol. 1, No.1.

[2] Su, S.-W. (2012). The Various Concepts of Curriculum and the Factors Involved in Curriculamaking. Journal of Languange Teaching and Research, Vol. 3, No.1, 153-158.

[3] Souza, A. R., \& Downs, R. M. (1994). Geography for Life. Washington D.C: National Geographic and Exploration.

[4] Yunus, H. S. (2012, April 25). Konsep dan Pendekatan Geografi: Memaknai Hakikat Keilmuannya. Retrieved from Dr. Taufik Hery Purwanto, M.Si.: http://taufik.staff.ugm.ac.id

[5] Heiner, C., \& Rieger, G. (2016, October). The Carl Wieman Science Education Initiative. Retrieved from CWSEI: http://www.cwsei.ubc.ca

[6] Vavla, L. (2009). Benefits of Using Newspaper, Magazines, and Books in Clasroom. Linguistic and Communicative Performance Journal, Vol. 2, No. 2.

[7] Gall, M. D., Gall , J. P., \& Borg, W. R. (2003). Educational Research. United States of America: Pearson Education, Inc.

[8] Ministry of Education and Culture. 2016. Regulation of the Minister of Education and Culture No. 20 of 2016 on Competency Standards of Primary and Secondary Education Graduates. Jakarta.

[9] Ministry of Education and Culture. 2016. Regulation of the Minister of Education and Culture No. 21 of 2016 on Basic Content of Basic and Intermediate Education. Jakarta.

[10] Ministry of Education and Culture. 2016. Regulation of the Minister of Education and Culture No. 24 of 2016 on Core Competence and Basic Competence of Lessons in the Curriculum 2013 on Basic and Intermediate Education. Jakarta.

[11] Ministry of Education and Culture. 2016. Regulation of the Minister of Education and Culture No. 22 of 2016 on Standard Process of Primary and Secondary Education. Jakarta. 